\title{
Examinations of the carbon dioxide emission of the soil in the case of different tillage methods in a field experiment
}

\author{
Ágnes Törö - Péter Ragán - Tamás Rátonyi - Endre Harsányi \\ University of Debrecen, Faculty of Agricultural and Food Sciences and Environmental Management, \\ Institute of Land Utilization, Technology and Regional Development, Debrecen \\ toro.agnes@agr.unideb.hu
}

SUMMARY

Today's global challenge is the increasing concentration of carbon dioxide $\left(\mathrm{CO}_{2}\right)$ and other greenhouse gases in the air. The level of $\mathrm{CO}$ emissions may be significantly affected by the agriculture and, more specifically, the applied tillage method, even though to a lesser extent than industrial production. On a global scale, the $\mathrm{CO}_{2}$ emission of an agricultural area is insignificant in comparison to that of a large-scale plant in an area of the same size, but areas under cultivation, including arable land, have a large global area. In this paper, we investigated the relationship between applied soil tillage methods and carbon dioxide emissions in the case of different fertiliser treatments. In our experiment we examined four types of tillage with five different fertiliser effects. Comparing fertiliser treatments and tillage methods, it was found that their interaction significantly affected carbon dioxide emissions, the lowest value was obtained in the case of the $210 \mathrm{l}$ ha ${ }^{-1}$ Nitrosol $+N-L O C K$ - tillage radish treatment. Strip and tillage radish methods have relatively homogeneous, low value.

Keywords: carbon dioxide emission, cultivation, fertilisation

\section{INTRODUCTION}

On the Earth, extreme weather conditions are becoming more common, which shows that human activity also influences the natural processes of the planet. The relationship between rising atmospheric concentrations of greenhouse gases and land use has been most studied in the United States since the 1980s, with the aim of reducing carbon dioxide emissions in the atmosphere as a result of emissions due to large plots (Lal et al. 1998ab). Agriculture accounts for only $5 \%$ of carbon dioxide emissions, including deforestation, biomass combustion and various arable operations (Láng 2003). As regards greenhouse gases, agriculture accounts for only $20 \%$ of them - methane of anthropogenic origin (50-70\%), $\mathrm{CO}_{2}(5 \%)$-, while land use deforestation and biomass combustion accounts for $14 \%$ (Cole 1996, Smith et al. 1997).

The carbon dioxide emissions of the soil are caused by the loss of organic matter and root respiration, which are affected also by soil temperature and moisture content (Goudriaan and Unsworth 1990, Fogarassy et al. 2008). In addition to environmental factors, carbon dioxide emissions are significantly affected by tillage. Intensive tillage methods significantly reduce the amount of carbon in soil, thus increasing carbon dioxide emissions (Birkás and Gyuricza 2004).

Kassam et al. (2012) investigated the cultivation methods, i.e., the degradation of organic matter is significantly facilitated by the greater aeration of the soil, the mixing of plant residues and the crushing of aggregates, concluding that the carbon stock of the soil is better preserved by the soil conservation tillage system and, in their opinion, the increasing carbondioxide emissions can even be reversed.

The role of moisture in carbon dioxide emissions is of particular importance, because the soil layers of the soil are filled with air, except for moisture. When more water is deposited in the soil, the air is discharged from the porous layers. Aeration has great importance in the topsoil (Stefanovits et al. 1999). Carbon dioxide produced during soil respiration is caused by root respiration, respiration of the soil fauna and the degradation of organic matter (Singh and Gupta 1977). Soil temperature also affects carbon dioxide emission, as it was described even by the equation of Arrhenius (1889) in the late $19^{\text {th }}$ century. However, tillage also has an impact on this factor as it may also disturb the temperature sensitivity of emissions. For this reason, it can be concluded, that the temperature sensitivity of the output is proportional to the intensity of tillage (Lascala et al. 2005). Emission is also influenced by the quality of the soil, as the organic matter stock of poor quality soil is smaller and; therefore, has lower emissions, while higher quality soils exhibit higher values in terms of emission (Kátai 1992).

Carbon-dioxide emissions have been examined both under laboratory and field circumstances. Experiments performed in the field are mostly carried out using the chamber method. Chamber sizes are variable; therefore, incubation period lengths also vary. The guiding principle of the performed examinations is the same: a previously specified part of the soil to be analysed is covered with a chamber, resulting in the exclusion of external effects and isolation. The amount of carbon dioxide emitted from the soil can thus be determined by comparing the initial and the final state of the carbon dioxide (Singh and Gupta 1977).

From an environmental point of view, the aim is to select soil protection methods that disturb the soil structure the least, as conventional (intensive) cultivation results in a $30-50 \%$ reduction in soil carbon stock (Cole 1996). In addition, the soil life is also adversely affected by the changing proportion of 
carbon dioxide, given the fact that it, meant soil life, got used $\mathrm{CO}_{2}$ to be around $6 \%$ so far (Kátai 2008).

Based on this research, it can be stated that the carbon dioxide cycle needs more attention because it plays a major role in global climate change.

\section{MATERIAL AND METHODS}

The aim of our experiment was to analyse the soil carbon dioxide emissions by examining the impact of different tillage methods and different fertiliser treatments. On the experiment site, four types of tillage were studied with five different fertiliser effects. The first part of the plot underwent autumn ploughing, the second was loosened, the third part underwent strip tillage and the fourth method was tillage radish. The experiment was performed in September 2017 on brown forest soil in the experiment site located near Dalmand (Picture 1).

Picture 1: The loosened treatment of the experimental site (Dalmand, 2017)

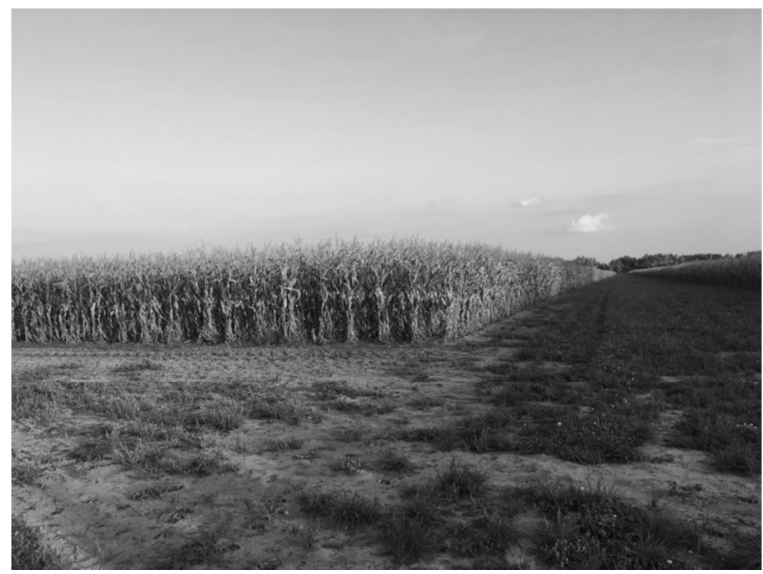

Source: own picture

Our measurements were performed using a Testo 535 device (Picture 2), which is a $\mathrm{CO}_{2}$ concentration measurement equipment infrared gas analyser working on the basis of infrared absorption. Unique cylinders were mounted in the ground with internal ventilation of the same diameter $(118 \times 250 \mathrm{~mm})$. Sampling points were randomly placed on each plot and the cylinders were lowered $5 \mathrm{~cm}$ deep in the ground, making sure that the soil was less disturbed at those points, so that we could measure emissions in the most natural microclimate. On the soil, the five cylinders, placed side by side, measured the initial carbon dioxide value and, based on our previous sampling experience we repeated the measurement after five minutes of incubation. Once the measurements were finished, the sampling cylinders were prepared for the next measurement by cleaning and aerating them.

Significant differences were analysed in the RStudio statistical system. Analytical values were measured in ppm which was converted to $\mathrm{g} \mathrm{m}^{-2} \mathrm{~h}^{-1}$ using the following formula (Kovács 2014):

$$
\mathrm{F}=\mathrm{d} *(\mathrm{~V} / \mathrm{A}) *\left(\mathrm{C}_{2}-\mathrm{C}_{1}\right) / \mathrm{t} * 273 /(273+\mathrm{T})
$$

Fertiliser treatments were different in each plot. The first plot was a control plot in all four tillage methods, i.e., no fertiliser was applied. The other plots were treated with top dressing and fungicide, but the rest of treatments were different. Further fertiliser management steps and plot identifiers are shown in table (Table 1), where the first member of the plot identifier is the location of the experiment, the second is the fertiliser treatment, and the third indicates the applied tillage method.

Table 1

Plot identifiers and fertiliser management steps

\begin{tabular}{rc}
\hline Plot identifiers & Fertiliser treatments \\
\hline $5.2 .1,5.2 .2,5.2 .3,5.2 .4$ & $1301 \mathrm{ha}^{-1}$ Nitrosol \\
$5.3 .1,5.3 .2,5.3 .3,5.3 .4$ & $2101 \mathrm{ha}^{-1}$ Nitrosol \\
$5.4 .1,5.4 .2,5.4 .3,5.4 .4$ & $2101 \mathrm{ha}^{-1} \mathrm{Nitrosol+N}^{-L O C K}$ \\
$5.5 .1,5.5 .2,5.5 .3,5.5 .4$ & $3401 \mathrm{ha}^{-1}$ Nitrosol \\
$5.6 .1,5.6 .2,5.6 .3,5.6 .4$ & $3401 \mathrm{ha}^{-1} \mathrm{Nitrosol+N}^{-L O C K}$
\end{tabular}

Picture 2: The measurement with the TESTO 535 gas analyser in the experimental plot

(Dalmand, 2017)

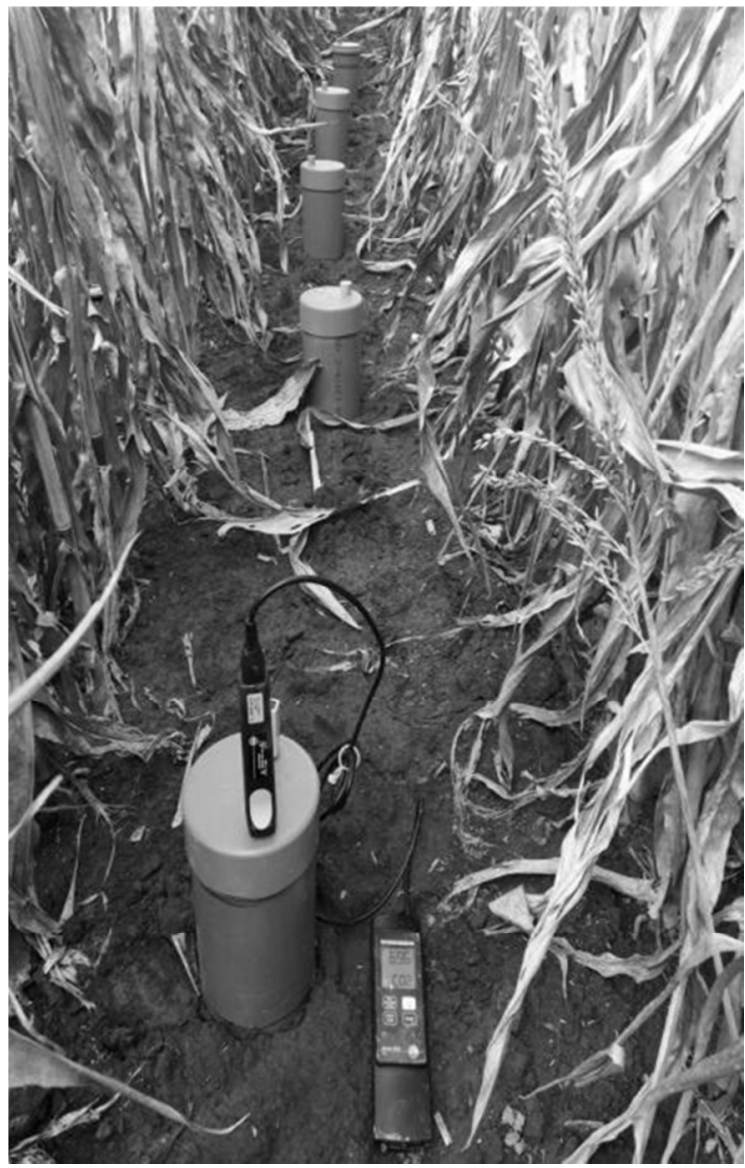

Source: own picture 


\section{RESULTS}

During the examination, we analysed the effect of fertiliser treatments and tillage on carbon dioxide emissions. Based on the statistical analysis, the fertiliser treatment alone did not have a significant effect on emissions ( $\mathrm{P}<0.01)$, but the effect of tillage is clearly detectable, as are the common effects of tillage and fertiliser treatments (Table 2).

The common effects of tillage and fertiliser treatments

\begin{tabular}{lccrrr}
\hline & Df & Sum Sq & Mean Sq & F value & Pr $(>\mathrm{F})$ \\
\hline Fertiliser & 5 & 0.393 & 0.0786 & 1.090 & $0.371^{\text {ns }}$ \\
Tillage & 3 & 4.491 & 1.4970 & 20.747 & $1.91 \mathrm{e}-10 * * *$ \\
Fertiliser*tillage & 15 & 4.033 & 0.2689 & 3.726 & $3.85 \mathrm{e}-05 * * *$ \\
Residuals & 96 & 6.927 & 0.0722 & & \\
\hline
\end{tabular}

Note: Signif. codes: $* * * 0.001 \%$; ns= non-significant

The effect of tillage was analysed with a post hoc test, according to Huzsvai, which showed a significant difference $(\mathrm{p}<0.01)$ between loosened and ploughed, as well as between tillage radish and strip tillage methods. The loosened and ploughing tillage methods showed almost the same values, the emission value did not differ significantly during the examined period. The tillage radish and strip tillage methods had significantly lower emission values $\left(0.51 \mathrm{~g} \mathrm{~m}^{-2} \mathrm{~h}^{-1}\right.$ and $\left.0.50 \mathrm{~g} \mathrm{~m}^{-2} \mathrm{~h}^{-1}\right)$. The lowest value was measured in the case of the tillage radish method, which was $0.3001 \mathrm{~g}$ $\mathrm{m}^{-2} \mathrm{~h}^{-1}$, while the highest value was observed in the case of loosening $\left(2.3955 \mathrm{~g} \mathrm{~m}^{-2} \mathrm{~h}^{-1}\right)$. The lowest difference in significance was 0.1376714 (Figure 1).

When comparing fertiliser treatments and tillage methods, it was found that their interaction significantly affected carbon dioxide emissions ( $P$ $<0.01)$. The highest values were obtained in the case of $210 \mathrm{l} \mathrm{ha}^{-1}$ Nitrosol+N-LOCK - in the ploughing treatment $\left(1.45 \mathrm{~g} \mathrm{~m}^{-2} \mathrm{~h}^{-1}\right)$, while the lowest value was obtained in the case of the $2101 \mathrm{ha}^{-1}$ Nitrosol+NLOCK -tillage radish treatment $\left(0.42 \mathrm{~g} \mathrm{~m}^{-2} \mathrm{~h}^{-1}\right)$.
The obtained values are higher in the case of the ploughed and loosened soils and there are two extreme values, both of which were measured in the loosening tillage method and $1301 \mathrm{ha}^{-1}$ Nitrosol+N-LOCK fertiliser $1.26 \mathrm{~g} \mathrm{~m}^{-2} \mathrm{~h}^{-1}$ and $340 \mathrm{l} \mathrm{ha}^{-1}$ Nitrosol+NLOCK fertiliser $\left(1.00 \mathrm{~g} \mathrm{~m}^{-2} \mathrm{~h}^{-1}\right)$. Strip and tillage radish methods have relatively homogeneous, low values (Figure 2).

Figure 1: The effect of the tillage on the $\mathrm{CO}_{2}$ emission of the soil (Dalmand, 2017)

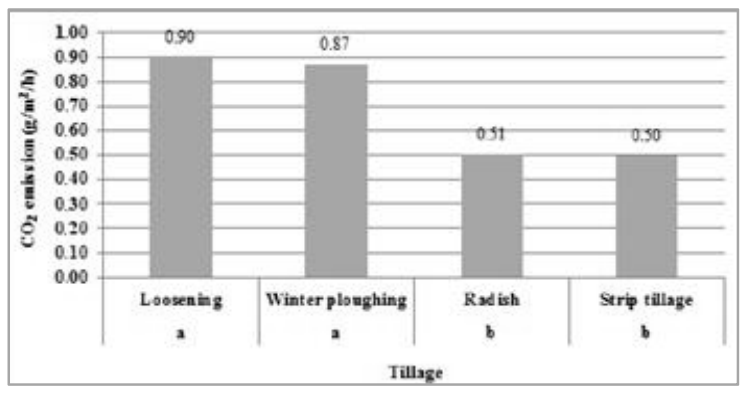

Figure 2: The effect of interaction between the cultivation method and the fertiliser treatments on the $\mathrm{CO}_{2}$ emission of soil

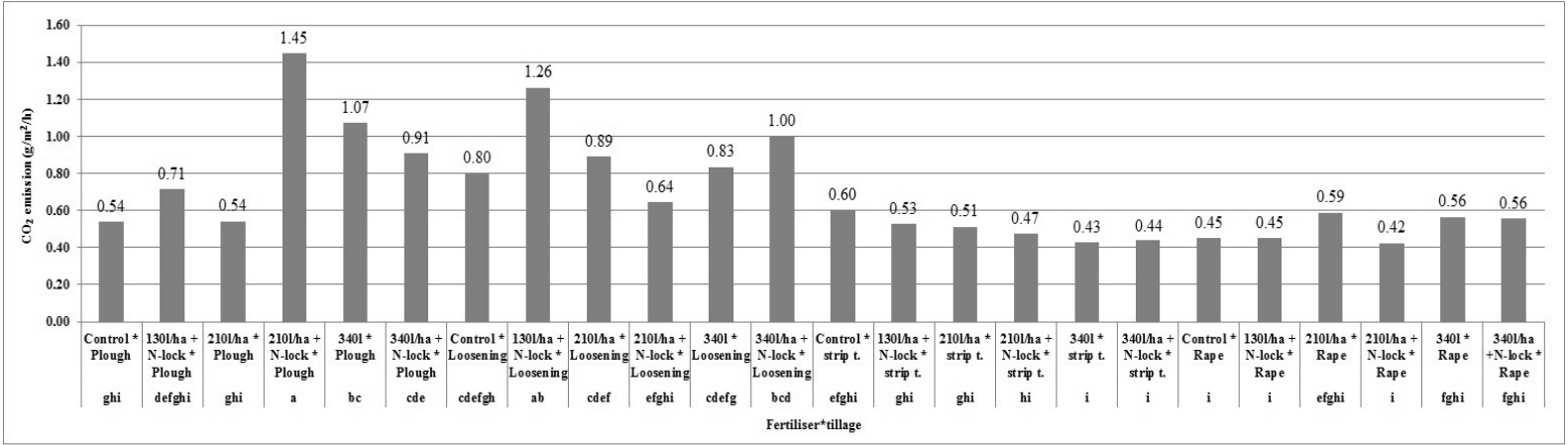

\section{CONCLUSIONS}

The carbon dioxide emission in the soil is a complex issue, influenced by a number of factors such as soil moisture and temperature, or tillage. Our experiment was looking for correlations between carbon dioxide emissions, tillage methods and the effect of fertilisation. The obtained test results have shown that less disturbed soil provides a greater chance of carbon sequestration in the soil, thereby reducing carbon dioxide emissions. 
According to the various analysis, the greatest difference between the obtained results was shown in tillage, while fertilisation did not significantly influence the carbon dioxide emissions, except if examined in conjunction with tillage. We plan to perform further measurements in the future.

\section{ACKNOWLEDGEMENT}

The work/publication is supported by the EFOP3.6.3-VEKOP-16-2017-00008 project. The project is co-financed by the European Union and the European Social Fund and grant from "Establishing a scaleindependent complex precision consultancy system" (GINOP-2.2.1-15-2016-00001) project.

\section{REFERENCES}

Arrhenius, S. (1889): Über die Reaktionsgeschwindigkeit bei der Inversion von Rohrzucker durch Säuren. Zeitschrift für physikalische Chemie. 4: 226-248.

Birkás M.-Gyuricza Cs. (2004): A talajhasználat és a klimatikus hatások kapcsolata. [In: Birkás M.-Gyuricza Cs. (szerk.) Talajhasználat, műveléshatás, talajnedvesség.] Quality-Press Nyomda \& Kiadó Kft. 10-47.

Cole, C. V. (1996): Intergovernmental Panel on Climate Change, 1995. Agricultural options for mitigation of greenhouse gas emission IPCC Working Group 11, Chapter 23, Washington. D.C.

Fogarassy, Cs.-Lukács, Á.-Böröcz, M. (2008): Basic structure of $\mathrm{CO}_{2}$ emission management practice in agricultural land use. Cereal Res. Commun. 36: 327-330.

Goudriaan, J.-Unsworth, M. H. (1990): In: Laegreid, M. et al. Agriculture, Fertilizers and the Environment. CABI Publishing. University Press. Cambrige. UK. 67.

Kassam, A.-Friedrich, T.-Derpsch, R.-Lahmar, R.-Mrabet, R.Basch, G.-González-Sánchez, E. J.-Serraj, R. (2012): Conservation agriculture in the dry Mediterranean climate. Field Crops Research. 132: 7-17.
Kátai J. (1992): Kölcsönhatások a talajtulajdonságok, néhány agrotechnikai eljárás és mikrobiológiai aktivitás között. Kandidátusi értekezés. Debrecen.

Kovács Gy. (2014): Mezőgazdasági hasznosítású talajok széndioxid emissziójának vizsgálata Karcag térségében. Doktori $(\mathrm{PhD})$ értekezés. Debrecen.

Lal, R.-Kimble, J.-Follett, R.-Steward, B. A. (eds.) (1998a): Soil processes and the $\mathrm{C}$ cycle. Boca Raton. FL. CRC Press.

Lal, R.-Kimble, J.-Follett, R.-Steward, B. A. (eds.) (1998b): Management of carbon sequestration in soil. CRC Press. Boca Raton. FL. USA.

Láng I. (2003): Agrártermelés és globális környezetterhelés. Mezőgazda Kiadó. Budapest. 215.

Lascala, J. R. N.-Lopes, A.-Panosso, A. R.-Camara, F. T.-Pereira, G. T. (2005): Soil $\mathrm{CO}_{2}$ efflux following rotary tillage of a tropical soil. Soil and Tillage Research. 84: 222-225.

Singh, J. S.-Gupta, S. R. (1977): Plant decomposition and soil respiration in terrestrial ecosystems. Botanical Review. 43: 449-528.

Stefanovits P.-Filep G.-Füleky Gy. (szerk.) (1999): Talajtan. Mezőgazda Kiadó. Budapest. 